\title{
A Phase I study of an HLA-DPB1*0401-restricted $T$ cell receptor targeting MAGE-A3 for patients with metastatic cancers
}

\author{
Yong-Chen Lu ${ }^{1 *}$, Linda Parker ${ }^{2}$, Tangying Lu², Zhili Zheng ${ }^{2}$, Xin Yao ${ }^{2}$, Paul F Robbins ${ }^{1}$, Pierre van der Bruggen ${ }^{3}$, \\ Christopher A Klebanoff ${ }^{4}$, Christian S Hinrichs', Stephanie Goff' ${ }^{1}$, Richard Sherry², Udai Kammula ${ }^{2}$, James C Yang ${ }^{2}$, \\ Steven A Rosenberg ${ }^{5}$
}

From 30th Annual Meeting and Associated Programs of the Society for Immunotherapy of Cancer (SITC 2015) National Harbor, MD, USA. 4-8 November 2015

\section{Background}

Adoptive transfer of genetically-modified $\mathrm{T}$ cells is being explored as a salvage treatment for patients with selected metastatic cancers. Most of the current strategies utilize MHC class I-restricted T cell receptor (TCR) or chimeric antigen receptor (CAR) technologies to genetically modify CD8 $+\mathrm{T}$ cells or bulk $\mathrm{T}$ cells for patient treatment. Evidence indicates that $\mathrm{CD} 4+\mathrm{T}$ cells can induce tumor regression, similar to $\mathrm{CD} 8+\mathrm{T}$ cells. To test this hypothesis, an HLA-DPB1*0401-restricted TCR recognizing MAGE-A3 was isolated from a patient's peripheral blood after MAGE-A3 peptide vaccination. Because HLA-DPB1*0401 is present in 40 70\% of the Caucasian population and MAGE-A3 is expressed in up to one third of tumor specimens from a variety of cancer types, this TCR immunotherapy can potentially be beneficial for a significant portion of cancer patients.

\section{Trial design}

Eligible patients were HLA-DPB1*0401 positive with MAGE-A3 positive tumor specimens, and had not responded or had recurred following at least one standard first line therapy for their disease. Patients received a lymphodepleting preparative regimen, followed by adoptive transfer of purified $\mathrm{CD} 4+\mathrm{T}$ cells transduced with the HLA-DPB1*0401-restricted MAGE-A3 TCR plus systemic high-dose interleukin-2 (IL-2). A cell doseescalation was conducted, treating 1 patient at each cohort $(0.01,0.03,0.1$, up to 30 billion cells), followed by
6 patients at the highest dose level (100 billion cells). Clinical trial information: NCT02111850.

\section{Results}

To date, 10 patients have been enrolled in this protocol. The latest patient was treated at the highest dose level (100 billion cells). A patient with cervical cancer metastases in her supraclavicular lymph nodes is a confirmed partial responder (PR) by RECIST criteria. Her tumors shrank $85 \%$ by 8 months after adoptive transfer of 3 billion TCR-transduced CD4+ T cells. This result demonstrates the safety of administering autologous $\mathrm{CD} 4+\mathrm{T}$ cells genetically-engineered to express an MHC class IIrestricted anti-tumor TCR targeting MAGE-A3 and presents preliminary evidence for efficacy. This clinical trial extends the reach of TCR gene therapy for patients with metastatic cancers. To our knowledge, this is the first genetically-modified CD4+ T cell immunotherapy against cancer.

\section{Trial registration}

ClinicalTrials.gov identifier NCT02111850.

\begin{abstract}
Authors' details
'Surgery Branch / National Cancer Institute / National Institutes of Health, Bethesda, MD, USA. ${ }^{2}$ National Institutes of Health, Bethesda, MD, USA ${ }^{3}$ Ludwig Institute for Cancer Research, de Duve Institute, Université Catholique de Louvain. Avenue Hippocrate 74, bte B1.74.03, second floor, Brussels, Belgium. ${ }^{4}$ Center for Cancer Research, NCI/NIH, Bethesda, MD, USA. ${ }^{5} \mathrm{NIH} / \mathrm{NCl}$, Bethesda, MD, USA.
\end{abstract}


- Convenient online submission

- Thorough peer review

- No space constraints or color figure charges

- Immediate publication on acceptance

- Inclusion in PubMed, CAS, Scopus and Google Scholar

- Research which is freely available for redistribution 